\title{
Penerapan On The Job Training Terhadap Keterampilan Kerja Pegawai Frontliner Pt.Transrekreasindo Surabaya
}

\author{
Ayu Zumatul Atiqoh ${ }^{1}$, Mustaji $^{2}$, Andi Mariono ${ }^{3}$ \\ ${ }^{123}$ Teknologi Pendidikan Pascasarjana Universitas Negeri Surabaya \\ Email: ayu.19010@mhs.unesa.ac.id ${ }^{1}$, mustaji@unesa.ac.id ${ }^{2}$ andimariono@unesa.ac.id $^{3}$
}

\begin{abstract}
This study aims to determine the effect of implementing on the job training on the performance skills of frontliner employees. The type of research used is experimental with a quantitative approach and the research design is quasiexperimental. The population in this study was 60 employees from 3 different branches. The purpose of data analysis is to determine the magnitude of the relationship and the effect of the independent variable (X) on the dependent variable (Y). The results obtained by linear regression test which shows that the effect of on the job training on job skills is $73.9 \%$, of which the rest is influenced by other factors. The t-count value of 6.060 with a sig value of $0.000<0.05$ can be interpreted that there is a significant influence between on the job training on employee work skills. So that it proves that all that can be drawn from the results of the analysis is that there is a significant influence between the application of on the job training to the work skills of frontliner employees of PT. Transrekreasindo Surabaya.
\end{abstract}

Keywords: On the job training, work skill, frontliner

\begin{abstract}
Abstrak. Penelitian ini bertujuan untuk mengetahui pengaruh penerapan on the job training terhadap keterampilan kinerja pegawai frontliner. Jenis penelitian yang digunakan adalah Ekperimen dengan pendekatan kuantitatif dan dengan desain penelitian yaitu quasi experiment. Jumlah populasi dalam penelitian ini sebanyak 60 karyawan dari 3 cabang yang berbeda. Analisis data tujuannya digunakan untuk mengetahui besarnya hubungan dan pengaruh variabel bebas (X) terhadap variabel terikat (Y). Hasil penelitian diperoleh uji regresi linier bahwa yang menunjukkan bahwa pegaruh on the job training terhadap keterampilan kerja sebesar $73,9 \%$ yang mana sisanya dipengarui factor lain. Nilai $t$ hitung sebesar 6,060 dengan nilai sig $0,000<0,05$ dapat diinterpretasikan bahwa ada pengaruh yang signifikan antara on the job training terhadap keterampilan kerja pegawai. Sehingga membuktikan keseluruhan yang dapat ditarik dari hasil analisis terdapat pengaruh yang signifikan antara penerapan on the job training terhadap keterampulan kerja pegawai frontliner PT. Transrekreasindo Surabaya.
\end{abstract}

Kata Kunci: On the job training, Keterampilan kerja, pegawai front liner

\section{PENDAHULUAN}

Belajar di tempat kerja dapat diartikan sebagai adanya kegiatan pelatihan, tes, seminar, dan lain-lain yang diselenggarakan oleh perusahaan. Kegiatan yang berlangsung pada perusahaan adalah pelatihan, baik pelatihan bagi karyawan baru dan karyawan yang sudah ada untuk menambah pengetahuan dan keterampilan agar dapat memenuhi standar perusahaan sendiri. Pelatihan merupakan rangkaian kegiatan pribadi yang bertujuan untuk meningkatkan keterampilan secara sistematis sehingga dapat menunjukkan profesionalisme bidangnya masing-masing. Pelatihan dapat diartikan sebagai runtutan perubahan pada pembelajaran yang memungkinkan karyawan melaksanakan pekerjaannya saat ini sesuai standar (Widodo, 2015: 82).

Pelatihan adalah inti dari manajemen, karena pelatihan akan menunjukkan kepada banyak pihak bagaimana melakukan sesuatu. Tanpa pelatihan, tidak mungkin pekerjaan dilakukan atau melakukan pekerjaan dengan benar. Blanchard\&Thacker (2012:165) mengartikan bahwa sistem pelatihan yang efisien terdiri dari serangkaian proses yang dirancang untuk mengubah semua faktor kebutuhan yang teridentifikasi menjadi hasil untuk mencapai tujuan perusahaan. Oleh karena itu, pelatihan sebenarnya merupakan fungsi yang berkelanjutan. Tata pengaturan kerja harus memberi kesempatan, baik untuk pelatihan maupun pengembangan. Hal tesebut bermaksud 
untuk menghubungkan program-program pelatihan dalam kebutuhan-kebutuhan tertentu dari organisasi. Dengan mempertimbangkan kebutuhan organisasi, metode pelatihan dapat di programkan sehingga pelatihan yang diadakan akan berfungsi secara maksimal. Menurut Manullang (2001) tujuan pelatihan ialah untuk memperoleh hal-hal yang efektif yaitu, untuk memperluas pengetahuan, memperluas keterampilan, dan memperbaiki system kerja.

Setelah melakukan observasi secara keseluruhan tentang sistem kerja, pengetahuan dan keterampilan yang dimiliki oleh pegawai dari PT. Transrekreasindo belum dapat dipastikan karena belum adanya data yang menunjukkan bahwa para pegawai telah mencapai standar kerja dan tujuan dari perusahaan. PT. Transrekreasindo adalah perusahaan yang bergerak di bidang jasa dan hiburan yang dikenal dengan arena bermain trans studio mini. Dimana standar kerja untuk para pegawai yaitu dapat mengoperasikan wahana permainan sesuai standart yang dimiliki oleh perusahaan dan dapat melayani pengunjung sesuai dengan standar yang di tetapkan.

PT. Trans Rekreasindo merupakan salah satu organisasi yang tidak mempunyai program pelatihan yang formal, selama ini para pegawai melakukan pelatihan yang tidak direncanakan dalam arti lain para pegawai menerapkan sistem learning by doing atau belajar secara spontan. Pelatihan yang tidak direncakan seperti ini biasanya tidak efisien dan tidak dapat diukur keberhasilannya. Fungsi dan deskripsi pekerjaan tidak dapat di evaluasi karena program pelatihan belum terbentuk sehingga perusahaan belum dapat mengetahui apakah para pegawainya memenuhi standar dan tujuan dari perusahaan. Pemimpin perlu mengevaluasi kinerja karyawannya. Tujuannya untuk karyawan lebih mudah berkembang, dan untuk mengukur sejauh mana karyawan bekerja kegiatan learning by doing atau belajar secara spontan dirasa kurang efektif. Hingga saat ini ketika penelitian ini dilakukan belum pernah menerepkan pelatihan formal, sehingga mencermati hal ini peneliti tertarik untuk mengkaji bagaimana penerapkan on the job training untuk para pegawai front liner (bagian depan) dan apakah penerapan on the job training dapat meningkatkan keterampilan kerja para pegawai sehingga dimasa depan keterampilan yang dimiliki dapat sesuai dengan standar perusahaan.

Metode-metode dari pelatihan ada bermacam-macam jenisnya, disesuaikan dengan tujuan dan fungsi pelatihan yang ada, job training merupakan metode yang paling tepat jika diaplikasikan di PT.Trans Rekreasindo karena job training dapat dilakukan di tempat kerja. Pelatihan ini memiliki banyak keuntungan karena kesederhanannya, bersifat realistis, hemat, dan tidak memerlukan peralihan dari ruang kelas belajar ke pekerjaan. On the job training adalah usaha terencana yang bertujuan untuk mendorong karyawan mempelajari pengetahuan, keterampilan, dan perilaku terkait pekerjaan, dalam arti sederhana On the job training adalah berlatih pada waktu bekerja. Dengan di terapkkannya pelatihan dengan metode yang sesuai, hasil yang dapat dirasakan diantaranya yaitu dapat memperbaiki metode dan sistem kerja, memperbaiki mutu dari pekerjaan, dapat mengurangi keluhan-keluhan, perbaikan komunikasi, pengurangan dalam angka kecelakaan kerja, perbaikan ketidakstabilan pegawai. Hasil yang dapat dicapai juga dapat dirasakan oleh pegawai yaitu kepuasan pengawai dapat bertambah karena diberikan pengetahuan dan keterampilan baru, kerjasama antar pegawai akan lebih besar, dan tanggungjawab moril lebih baik. Menurut Moekijat, (1991:33) dengan intruksi yang baik on the job training dimungkinkan merupakan salah satu pelatihan yang paling efektif untuk latihan yang cepat bagi pekerja-pekerja yang tidak atau yang setengah cakap.

On the job training bersifat praktis dan tempat memberi pengajaran didasarkan pada kondisi kerja. Pelatihan ini bertujuan untuk membekali karyawan dengan keterampilan yang dibutuhkan untuk pekerjaan tertentu, dan pelatihan bertujuan untuk mengisi kesenjangan antara kemampuan yang dapat diberikan pekerja 
dan kemampuan yang diperlukan untuk pekerjaan tersebut. Sehingga di harapkan dengan adanya penelitian ini, mampu menerapkan on the job training untuk memberikan dampak keterampilan yang sesuai dengan standart perusahaan PT. Transrekreasindo.

\section{TINJAUAN PUSTAKA}

\section{On th Job Training}

Frazis dan Loewenstein (2006) mengatakan bahwa On the job training merupakan analisis tentang bagaimana individu memperoleh dan dibayar untuk keterampilan mereka. Pekerja mengembangkan banyak keterampilan melalui pendidikan formal yang tidak terikat pada pemberi kerja, tetapi bagian penting dari keterampilan mereka dipelajari di tempat kerja melalui pelatihan langsung. Metode atau cara atau teknik on the job training yang digunakan dalam penelitian adalah metode coaching.

\section{Keterampilan Kerja}

Menurut Spencer dikutip oleh Sutoto (2004:1-10), kelompok keterampilan diantaranya meliputi kompetensi concern for order (CO), initiative (INT), impact and influence (IMP), dan information seeking (INFO). Disimpulkan kompetensi keterampilan kerja yang harus dimiliki oleh para pegawai front liner PT. Transrekreasindo adalah sebagai berikut :

1) Memiliki gerak kerja atau cara kerja yang cepat dan tepat dalam kondisi mengevakuasi wahana bermain

2) Memiliki keterampilan dalam mempengaruhi pelanggan sehingga tertarik untuk bermain.

3) Keterampilan melayani pelanggan dapat meningkat disesuaikan pada standar perusahaan.

\section{Kinerja Pegawai}

Mangkunegara (2014: 67) berpendapat, kinerja pegawai mengacu pada prestasi pekerjaan atau hasil dari kerja yang dicapai oleh sumber daya manusia dalam hal mutu dan kuantitas pada saat mengerjakan tugas pekerjaannya sesuai dengan tanggungjawab yang telah diberikan dalam kurun waktu yang sama. Rivai (2005: 309) mengemukakan bahwa kinerja merupakan salah satu fungsi dari motivasi dalam diri dan kemampuan yang dimiliki seseorang dalam menyelesaikan suatu tugas atau pekerjaan yang diberikan. Kinerja diartikan sebagai perilaku nampak yang diperlihatkan oleh setiap individu sebagai hasil kerja yang dihasilkan oleh pegawai sesuai dengan peran karyawan tersebut di perusahaan. Kinerja juga meliputi hasil kerja yang erat kaitannya dengan kepuasan atau service, konsumen, tujuan strategis perusahaan, dan memiliki kontribusi terhadap perekonomian, sehingga sebagian orang berusaha melakukan pekerjaan tersebut dan mendapatkan hasil darinya. Untuk dapat meningkatkan produktivitas dan mengevaluasi kinerja karyawan atau organisasi, diperlukan indikator yang terukur Menurut penelitian Keith Davis dalam Mangkunegara (2014: 61), kinerja pegawai dapat dilihat dengan indikator yaitu

1) Kualitas Kerja

2) Kuantitas Kerja

3) Pelaksanaan Tugas

4) Kerjasama

5) Inisiatif

\section{METODE PENELITIAN}

Pada penelitian ini jenis penelitian yang dipergunakan ialah jenis penelitian eksperimen. Penelitian eksperimen adalah penelitian yang memiliki tujuan untuk mengetahui adanya pengaruh variabel tertentu terhadap variabel lain dalam kondisi yang terkontrol dengan ketat. Pendekatan penelitian berdasarkan sifat datanya dalam penelitian ini adalah pendekatan dengan pendekatan kuantitatif, yang mana data yang dikumpulkan berupa angka statistik.

Desain penelitian yang digunakan dalam penelitian ini menggunakan quasi experimental dimana desain penelitian ini merupakan penelitian eksperimen yang menggunakan perlakuan pengaruh dan unit eksperimen tidak menggunakan penugasan secara acak untuk dapat membuat perbandingan yang digunakan menarik kesimpulan tentang 
perubahan yang disebabkan oleh adanya perlakuan (Arikunto, 2006:125).

\begin{tabular}{|c|c|c|c|}
\hline Kelompok & Pre-test & Perlakuan & Post-test \\
\hline E & O1 & X & O2 \\
\hline K & O3 & - & O4 \\
\hline
\end{tabular}

Variablel-variabel yang digunakan adalah Variabel Bebas (X) : On the Job Training;Variabel Terikat (Y1) : Keterampilan Kerja Pegawai. Dalam penelitian ini peneliti mengambil populasi seluruh pegawai front liner yang ada di Trans Studio Mini Surabaya yang memiliki 3 cabang yaitu Rungkut, Ngagel, dan Sidoarjo dengan total subjek pegawai 60 orang. Dalam penelitian ini kelompok ekperimen adalah cabang rungkut dan sidoarjo yang terdiri dari 30 orang pegawai, dan 30 orang dari cabang Ngagel sebagai kelas kontrol. Dengan teknik pengumpulan data observasi, tes, dan angket.

\section{Teknik Pengumpulan Data}

\section{Teknik Analisis Data}

\section{Analisis Data Hasil Observasi dan Angket}

Data hasil angket berasal dari hasil jawaban berupa angket tertutup yang diberikan kepada para pegawai. Data ini akan menunjukkan nilai positif atau negatif dari dampak pelatihan yang sudah dilakukan. Angka persentase diperoleh dengan rumus menurut Ali, M (2002:187) yaitu

$$
\mathrm{P}=\frac{f}{n} x 100 \%
$$

Keterangan :

$$
\begin{aligned}
& \mathrm{P}: \text { Persentase } \\
& \mathrm{f}: \text { Frekuensi Data } \\
& \mathrm{n} \text { : Jumlah Responden } \\
& \text { Pada analisis data hasil observasi, }
\end{aligned}
$$
acuan yang digunakan menggunakan skala Guttman. Dibuat dengan dua jawaban yakni "yatidak" (Sugiyono, 2013:139). Jawaban yang dibuat jawaban "ya" akan diberi nilai 1 dan "tidak" diberi nilai 0. Pada analisis data hasil angket dilakukan perhitungan dengan menggunakan teknik perhitungan Presentase yang menggunakan skala likert. Adapun kriteria penilaian (Arikunto, 2013:80) adalah sebagai berikut:

$$
\begin{array}{ll}
80 \%-100 \% & \text { : Sangat baik } \\
66 \%-79 \% & : \text { Baik } \\
40 \%-65 \% & : \text { Kurang baik } \\
0 \%-39 \% & \text { : Tidak baik }
\end{array}
$$

\section{Analisis Data hasil Tes}

Analisis hasil tes digunakan untuk membandingkan perolehan nilai hasil keterampilan kerja pegawai yang telah mendapatkan pelatihan dengan nilai hasil keterampilan pegawai yang tidak diberikan pelatihan yang diperoleh dari hasil pelaksanaan post-test, kemudia memasukkan rumus t-test menggunakan aplikasi SPSS. Menurut Arikunto (2013:124) yang digunakan adalah pretest dan posttest design sebagai berikut :

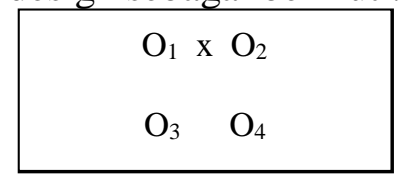

Keterangan :

$$
\begin{aligned}
\mathrm{O} 1, \mathrm{O} 3= & \text { tes yang dilakukan sebelum } \\
& \text { eksperimen (pre test) } \\
\mathrm{O} 2, \mathrm{O} 4= & \text { tes sesudah eksperimen (posttet) }
\end{aligned}
$$

\section{Uji Prasarat}

\section{Uji Normalitas}

Uji normalitas dipergunakan dengan tujuan untuk dapat mengetahui apakah sebaran semua data yang diperoleh mengikuti atau mendekati hukum distribusi normal standar Gauss. Uji normalitas dirancang untuk menunjukkan bahwa sampel data berasal dari populasi yang berdistribusi normal, yang dapat di ketahui dengan melihat hasil perhitungan signifikansi. Bila hasil signifikansi yang didapatkan > $a=0,05$, maka sample berasal dari populasi yang berdistribusi normal, namun bila nilai signifikansi yang didapakan $<a=0,05$, maka sampel tersebut bukan berasal dari populasi yang berdistribusi normal. (Ali, 2013:78). Perhitungan tersebut dilakukan mempernggunakan alat bantu apliasi SPSS

\section{Uji Homogernitas}

Uji homogenitas bertujuan untuk menunjukkan bahwa dua maupun lebih data sampel yang berasal dari suatu populasi dengan varians yang sama. Hal tersebut dapat diketahui 
melalui hasil perhitungan tingkat siginifikansi. Jika diperoleh tingkat signifikansi $>a=0,05$ maka varians dari masing-masing sampel tidak sama atau tidak merata atau tidak homogen (Ali, 2013: 87). Perhitungan tersebut akan menggunakan alat bantu program SPSS.

\section{Uji Regresi Linier}

Teknik uji regresi linear untuk menguji hipotesis penelitian menggunakan alat bantu program SPSS yang dipergunakan untuk melihat apakah terdapat pengaruh dari on the job training terhadap keterampilan kerja pegawai.

Dimana kriteria pengambil keputusan didasarkan pada nilai signifikansi (sig). Jika nilai sig lebih besar dari 0,05 atau sig >0,05 maka $\mathrm{H} 0$ diterima (tidak ada hubungan); jika nilai sig lebih kecil dari 0,05 atau sig < 0,05 maka H0 ditolak yang berarti memiliki hubungan.

\section{HASIL PENELITIAN DAN PEMBAHASAN}

Penelitian yang dilakukan di PT. Transrekreasindo Surabaya cabang Rungkut, Ngagel, dan Sidooarjo dengan subjek penelitian adalah pegawai dengan masa kerja atau pengalaman kerja 2 hingga 4 bulan. Hasil dari proses penelitian tersebut akan dibahas pada bab ini. Data yang diperoleh dari hasil penelitian akan dianalisis sehingga peneliti mendapatkan kebenaran dan kepastian dari hipotesis yang telah diajukan. Untuk mendapatkan kebenaran dari hipotesis yang dirumuskan oleh peneliti, maka data diambil berdasarkan observasi di lapangan lalu dibentuk menjadi sebuah instrument berupa tes, angket dan observasi.

Data-data yang nantinya didapat adalah data berupa angka-angka karena penelitian ini menggunakan penelitian kuantitatif. Angkaangka yang dihasilkan kemudian akan diolah dan dianalisis menggunakan cara-cara yang runtut melalui uji validitas, uji reabilitas, mencari garis regresi melalui persamaan $\mathrm{X}$ dan Y, dan koefisien korelasi. Sehingga melalui cara-cara tersebut diharapkan dapat menghasilkan suatu kesimpulan yang akan menjawab segala permasalahan yang telah dikemukakan oleh peneliti. Pada bab ini, ada tiga tahapan untuk mendapatkan hasil penelitian, yaitu deskripsi data, penyajian data dan hasil analisis data, pengujian hipotesis, kemudian pembahasan hasil penelitian yang akan diuraikan pada pembahasan berikut ini.

\section{Deskripsi Data}

Dalam mendeskripsikan bagaimana dan keterampilan kerja para pegawai terhadap penerapan On The Job Training dan untuk menguji apakah On the job training memiliki pengaruh terhadap keterampilan kerja, maka bagian ini disajikan deskripsi data dari masingmasing variabel sesuai data yang diperoleh dari lapangan selama penelitian berlangsung.

Sebagaimana telah dijelaskan dibab sebelumnya, bahwa responden yang ada pada penelitian ini adalah pegawai dengan masa kerja atau pengalaman kerja 2 hingga 4 bulan, yaitu sebanyak 60 pegawai yang terdiri dari 30 orang pegawai cabang rungkut dan sidoarjo untuk kelas eksperimen dan 30 orang pagawai dari cabang ngagel untuk kelas control.

Proses On the Job Training terhadap Keterampilan Pegawai Kelas Eksperimen (Rungkut dan Sidoarjo)

On the job training atau disebut juga pelatihan dengan instruksi pekerjaan sebagai suatu metode pelatihan dengan cara para pegawai ditempatkan dalam kondisi pekerjaan yang riil, dibawah bimbingan dan supervise dari karyawan yang telah berpengalaman atau terlatih. Metode Pelatihan yang digunakan adalah Cognitive Methods Approach dan Behavioral Methods Approach. Cognitive Methods Approach fokus pada pengembangan pengetahuan dengan memberikan informasi yang menunjukkan hubungan antar konsep atau memberikan aturan tentang cara melakukan sesuatu. Metode ini merangsang pembelajaran melalui pengaruhnya terhadap proses kognitif peserta pelatihan (Blanchard \& Thacker, 2013: 218).

Materi pengetahuan yang akan difokuskan pada penelitian ini mencakup pemahaman tugas atau job description pekerjaan yang dilakukan oleh pegawai kelas eksperimen di cabang Rungkut dan Sidoarjo. Materi tersebut meliputi aturan wahana, pelayanan, POS Kasir, 
dan standar operasional. Materi pemahaman ini bertujuan untuk memberikan bekal kepada para pegawai dalam menjalankan tugas di area kerja, sehingga pegawai dapat merasa cakap dalam hal pengetahuan yang dimiliki. Proses pemberian training ini dilakukan dengan metode penyampaian materi dengan orientasi di lapangan sehingga materi yang disampaikan akan bisa lebih dipahami oleh peserta training karena menyampaikan materi dengan situasi kerja yang nyata.

Metode Pelatihan selanjutnya yang digunakan adalah Behavioral Methods Approach yaitu fokus pada perilaku peserta pelatihan dalam situasi nyata atau disimulasikan. Metode ini dipilih karena baik digunakan untuk pengembangan keterampilan dan perubahan sikap. Materi keterampilan kerja ini mencakup serangkaian tugas yang akan dilakukan oleh para pegawai front liner yaitu tentang evakuasi wahana, pelayanan, berjualan dengan baik. Materi keterampilan ini disampaikan oleh supervisor atau trainer dengan mencontohkan dan praktek secara langsung di area kerja. Dalam penyampaian materi keterampilan kerja, supervisor melakukan pembinaan (coaching) dan pendampingan (mentoring) secara intens kepada para peserta pelatihan. Tujuan dari metari ini yaitu pegawai dapat meningkatkan dan memiliki gerak cepat dan tepat dalam menyelesaikan pekerjaan.

Proses pemberian training ini dilakukan dengan metode penyampaian materi dengan orientasi di lapangan sehingga materi yang disampaikan akan bisa lebih dipahami oleh peserta training karena menyampaikan materi dengan situasi kerja yang nyata. Berikut dapat dijabarkan mengenai matriks pelatihan materi pokok pemahaman keterampilan.

Tes

Data yang diperlukan untuk penerapan On the Job Training terhadap pemahaman keterampilan yaitu berupa validasi dari ahli materi, dimana data disperoleh dengan cara memberikan angket kepada ahli materi untuk divalidasi. Data hasil validasi dari ahli materi tersebut akan dipergunakan untuk menyatakan kevalid-an instrument tes pemahaman keterampilan. . Pada penelitian ini tes yang digunakan berupa pilihan ganda untuk mengukur pemahaman dan keterampilan kerja pada pegawai frontliner perusahaan Transrekreasindo dengan menggunakan pre-test dan post-test.

Validasi penerapan On the Job Training terhadap pemahaman keterampilan dilakukan oleh ahli materi yaitu Lina Maesari Agustin, S. Pd, M.M dengan kualifikasi sebagai Talent Acquisition Asst Manager PT. Transrekreasindo. Berdasarkan hasil isian angket oleh validator, dapat diketahui bahwa akan dilakukan perbaikan-perbaikan pada soal. Selanjutnya sesuai dengan rekapitulasi hasil data Hasil perhitungan data kuantitatif berdasarkan hasil data diatas ialah $: \mathrm{p}=14 / 15 \times 100 \%=93,33 \%$ Berdasarkan dari perhitungan menggunakan rumus presentase dari semua aspek diperoleh nilai sebesar 93,33\%. Menurut Arikunto (2014:35), presentase tersebut termasuk dalam kategori sangat baik. Maka dapat dinyatakan bahwa soal tes adalah sangat baik.

\section{Angket}

Peneliti menggunakan angket tertutup dalam penerapan on the job training yang akan digunakan untuk pegawai dalam mendapatkan data yang akan dipergunakan untuk menilai dampak. Data keterampilan kerja diperoleh dari penyebaran angket tertutup kepada responden dari kelas eksperimen sebanyak 30 pegawai, Untuk menyatakan bahwa instrument angket keterampilan tersebut valid untuk digunakan, maka perlu dilakukan validasi instrument oleh ahli, dimana peneliti menggunakan ahli yang expert dibidangnya dari PT. Transrekreasindo yaitu Indra Yutanto, SE. Berdasarkan hasil isian angket oleh validator, dapat diketahui bahwa angket yang diajukan tidak terdapat revisi. Hasil perhitungan data kuantitatif berdasarkan hasil data diatas ialah : $\mathrm{p}=19 / 20 \times 100 \%=95 \%$

Berdasarkan dari perhitungan menggunakan rumus presentase dari semua aspek diperoleh nilai sebesar 95\%. Menurut Arikunto (2014:35), presentase tersebut 
termasuk dalam kategori sangat baik. Maka dapat dinyatakan bahwa angket untuk pegawai adalah sangat baik.

\section{Observasi}

Dalam penelitian ini observasi dibutuhkan untuk melihat bagaimana keterampilan pegawai kelas eksperimen setelah diberikan perlakuan. Hasilnya diharapkan setelah melakukan on the job training, keterampilan yang dimiliki oleh pegawai mengalami perubahan atau peningkatan atau dalam hal ini apakah keterampilan yang dimiliki setelah menerapkan on the job training sesuai dengan intruksi kerja yang berlaku di perusahaan.

Validasi penerapan On the Job Training terhadap instrument validasi dilakukan oleh ahli yaitu Indra Yutanto, SE dengan kualifikasi sebagai Manager Training \& Development PT. Transrekreasindo, selanjutnya sesuai dengan rekapitulasi hasil data yaitu $\mathrm{p}=6 / 7 \quad \mathrm{x}$ $100 \%=85,71 \%$

Berdasarkan dari perhitungan menggunakan rumus presentase dari semua aspek diperoleh nilai sebesar $85,71 \%$. Menurut Arikunto (2014:35), presentase tersebut dalam kategori sangat baik. Maka dapat dinyatakan bahwa instrument observasi dan keterampilan adalah sangat baik.

\section{Penyajian Data dan Hasil Analisis Data Hasil Uji Validitas Instrumen Tes}

Uji validitas instrument tes ini dilakukan pada soal-soal untuk pre tes dan post tes yang berfungsi untuk untuk mengukur keterampilan kerja pada pegawai dengan menggunakan pre-test dan post-test. Pada penelitian ini ranah koginif yang akan dinilai adalah pemahaman karyawan dalam pekerjaan. Uji validitas ini dilakukan kepada pegawai yang berjumlah 20 orang dengan kualifikasi pegawai dengan masa kerja diatas 1,5 tahun dengan jumlah soal sebanyak 30 butir soal, pengujian dilakukan menggunakan aplikasi SPSS. Data hasil validitas instrument tes menggunakan SPSS dapat dijelaskan bahwa $\mathrm{N}=20$ dengan signifikansi $5 \%$ diketahui $\mathrm{r}$ tabel yaitu 0,444 dengan perbandingan nilai koefisien korelasi (Pearson Correlation) yang didapatkan, $r$ hitung yang didapatkan per butir soal sesuai dengan tabel diatas. Dengan kaidah jika r hitung > r tabel maka soal dinyatakan valid, sedangkan jika $r$ hitung < $\mathrm{r}$ tabel soal dinyatakan tidak valid. Diketahui bahwa jumlah soal sebanyak 30 terdapat 24 soal dinyatakan valid dan 6 soal dinyatakan tidak valid. Dan kesimpulan keseluruhan dari 30 soal dinyatakan valid dalam perhitungan SPSS.

\section{Hasil Uji Reliabilitas Instrumen Tes}

Uji reliabilitas merupakan uji yang dilaksanakan untuk mengukur tingkat konsistensi skor yang dicapai apabila tes dilakukan secara berulang-ulang. Instrumen penelitian selain harus valid atau sahih juga harus bersifat dapat dipercaya atau reliabel. Uji reliabilitas instrument tes dilakukan menggunakan aplikasi SPSS dan akan dijabarkan pada tabel 1.1 hasil uji reliabilitas instrument tes.

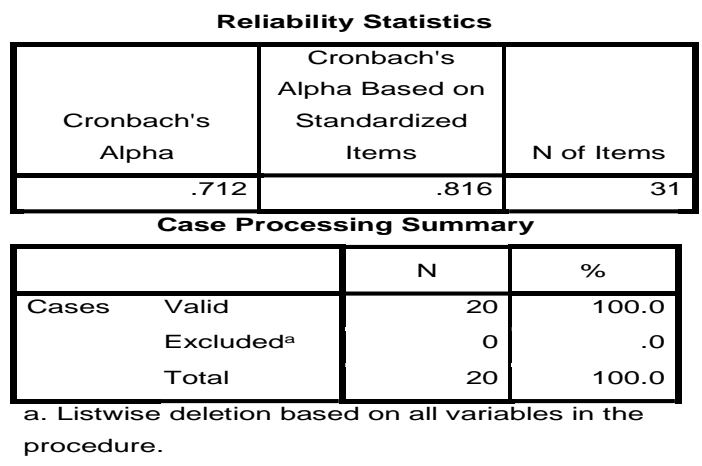

Berdasarkan hasil yang diperoleh dinyatakan bahwa $\mathrm{r}$ hitung adalah 0,712, sehingga dengan kategori koefisien reliabilitas (Guilford, 1956: 145) yaitu 0,60 < r11 0,80 termasuk dalam reliabilitas tinggi. Dan hasl tersebut dimaknai jika $\mathrm{r}$ hitung > $\mathrm{r}$ tabel maka soal dinyatakan reliabel, sedangkan jika $r$ hitung $<\mathrm{r}$ tabel berarti soal dinyatakan tidak reliabel. Maka dari hasil yang didapatkan pada tabel 4.8 yaitu $0,712>0,60$ yang berarti bahwa instrument soal tes memiliki realibilitas yang tinggi. 


\section{Hasil Uji Prasarat}

Untuk memenuhi syarat uji lebih lanjut secara parametric, makan dilaksanakan uji prasarat yang meliputi uji normalitas dan uji homogenitas terhadap nilai pre tes baik pada kelas kontrol maupun kelas eksperimen.

\section{Uji Normalitas}

Uji normalitas dilakukan untuk mengetahui sebaran baku normal atau tidak normal dengan menggunakan uji Kolmogorof Smirnof. Dengan pengambilan keputusan yaitu jika nilai signifikansi lebih dari 0,05 maka data tersebut berdistribusi normal, sedangkan jika nilai signifikansi lebih kecil dari 0,05 maka data dinyatakan tidak berdistribusi secara normal.

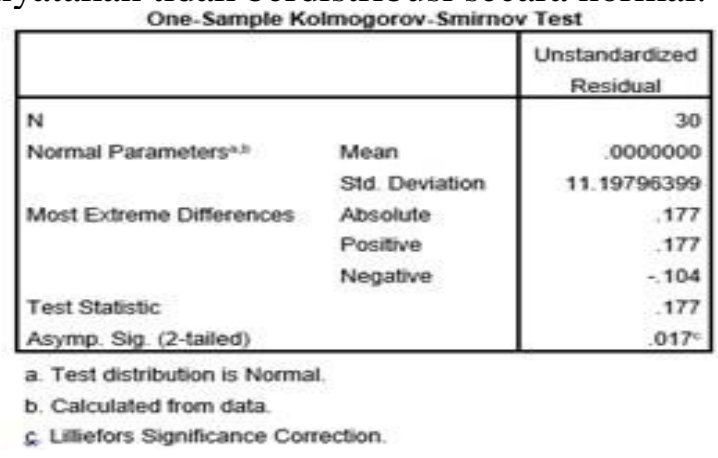

Berdasarkan tabel 1.2 diketahui bahwa untuk kelas eksperimen didapatkan 0,017 >0,05 sehingga disimpulkan bahwa data berdistribusi normal dan memenuhi syarat normalitas untuk dilanjutkan dengan uji berikutnya.

Tabel 1.3 Hasil Uji Normalitas Kelas Kontrol

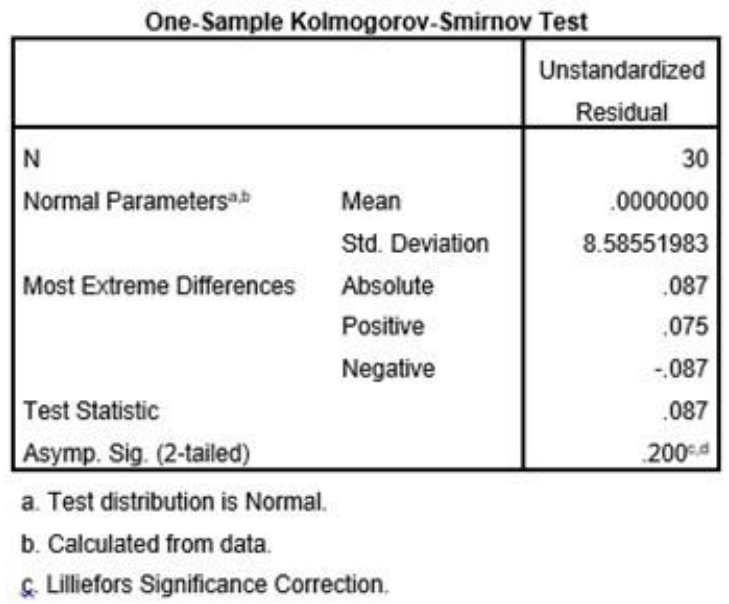

Berdasarkan tabel 1.3 diketahui bahwa untuk kelas kontrol didapatkan 0,200>0,05 sehingga disimpulkan bahwa data berdistribusi normal dan memenuhi syarat normalitas.

Uji Homogenitas

Selannjutnya uji yang dilakukan adalah uji homogenitas. Uji homogentitas bertujuan untuk mengetahui apakah suatu varians data dari dua atau lebih kelompok bersifat homogen atau sama. Pengambilan keputusan dalam uji homogenitas adalah jika nilai signifikansi, Sig > 0,05 maka varian dari kedua kelompok populasi data adalah sama atau homogen. Namun jika Sig $<0,05$ dikatakan bahwa varian tersebut tidak sama atau tidak homogeny. Berikut dijabarkan hasil dari uji homogenitas menggunakan aplikasi SPSS.

\begin{tabular}{|c|c|c|c|c|c|}
\hline & & Levene Statistic & dit & $\mathrm{d} 12$ & Siq \\
\hline \multirow[t]{4}{*}{ HASIL TES PEGAWAI } & Based on Mean & 194 & 1 & 58 & .661 \\
\hline & Based on Median & .169 & 1 & 58 & .683 \\
\hline & $\begin{array}{l}\text { Based on Median and with } \\
\text { adjusted of }\end{array}$ & .169 & 1 & 53.684 & 683 \\
\hline & Based on trimmed mean & 188 & 1 & 58 & .666 \\
\hline
\end{tabular}

Berdasarkan output diatas diketahui nilai signifikansi ( $\mathrm{Sig}$ ) based on mean adalah sebesar 0,661 >0,05, sehingga dapat disimpulkan bahwa varians kelompok kelas eksperimen dan kelas kontrol adalah sama atau homogen. Dengan demikian, maka salah satu syarat dari uji sample $t$ test sudah dapat terpenuhi.

Demi kesempurnaan syarat dalam uji hipotesis maka dilakukan uji independent sample t-test. Maknanya uji t merupakan analisis yang bertujuan untuk membandingkan dua sampel yang tidak saling berpasangan yang sudah berdistribusi normal dan bersifat homogen. Setelah uji t dihasilkan maka dari Group Statistics diketahui bahwa rata-rata (mean) pada kelas kontrol adalah 57,87 dan pada kelas eksperimen adalah 95,30. Dengan demikian secara deksriptif statistic dapat diseimpulkan ada perbedaan rata-rata hasil belajar dari kelas kontrol dan kelas eksperimen. Kemudian, pada tabel Independent Sample Test pada kolom Sig (2-tailed) sebesar 0,000 $<0,05$. Maka, dapat diketahui bahwa terdapat perbedaan pada rata-rata nilai posttest pada kelas kontrol dan rata-rata nilai post test pada kelas eksperimen. Kesimpulan yang dapat diperoleh 
dari hasil analisis pada kelas kontrol yang tidak menerapkan on the job training tidak terdapat pengaruh dari hasil pelatihan dan sebagaimana dasar pengambilan keputusan dalama uji independent sample $\mathrm{t}$ test dapat disimpulkan bahwa Ho ditolak yang berarti memiliki hubungan.

\section{Uji Regresi Linier}

Analisis Data Pengaruh on the job training terhadap keterampilan kerja pegawai PT. Transrekreasindo dengan tujuan melihat apakah terdapat pengaruh dari on the job training terhadap keterampilan kerja pegawai, maka dilakukan uji regresi linier.

Tabel 4.10 Hasil Uji Linier Model Summary

\begin{tabular}{|l|r|r|r|r|}
\hline Model & $\mathrm{R}$ & $\begin{array}{c}\mathrm{R} \\
\text { Square }\end{array}$ & $\begin{array}{c}\text { Adjuste } \\
\mathrm{d} \mathrm{R} \\
\text { Square }\end{array}$ & $\begin{array}{c}\text { Std. Error } \\
\text { of the } \\
\text { Estimate }\end{array}$ \\
\hline 1 & $.859^{\mathrm{a}}$ & .739 & .718 & 5.39221 \\
\hline
\end{tabular}
a. Predictors: (Constant), OJT

Berdasarakan uji regresi linier menggunakan alat bantu SPSS pada tabel diatas, diperoleh nilai R Square 0,739 atau 73,9\% yang menunjukkan bahwa pegaruh on the job training terhadap keterampilan kerja sebesar $73,9 \%$ yang mana sisanya dipengarui factor lain. Nilai $\mathrm{t}$ hitung sebesar 6,060 dengan nilai sig 0,000 < 0,05 dapat diinterpretasikan bahwa ada pengaruh yang signifikan antara on the job training terhadap keterampilan kerja pegawai.

\section{SIMPULAN}

Pelatihan ini bertujuan untuk membekali karyawan dengan keterampilan yang dibutuhkan untuk pekerjaan tertentu dan untuk mengisi kesenjangan antara kemampuan yang dapat diberikan dan kemampuan yang diperlukan untuk pekerjaan tersebut. Desain penelitian yang digunakan dalam penelitian ini menggunakan quasi experimental.

Tes berfungsi untuk untuk mengukur keterampilan kerja pada pegawai dengan menggunakan pre-test dan post-test. Berdasarkan hasil grafik diketahui bahwa hasil pre test untuk kelas ekperimen sebesar 47,23 dan untuk kelas control yaitu sebesar 49,89 Kesimpulan yang dapat diperoleh dari hasil pelatihan dan sebagaimana dasar pengambilan keputusan dalama uji independent sample $t$ test dapat disimpulkan bahwa Ho ditolak yang berarti memiliki hubungan.

\section{DAFTAR PUSTAKA}

Anwar Prabu Mangkunegara. (2014). Manajemen Sumber Daya Manusia Perusahaan. Bandung: Remaja Rosdakarya.

Arikunto, Suharsimi. (2009). Dasar Dasar Evaluasi Pendidikan. Jakarta:Bumi Aksara). Cetakan. IX

Blanchard, P. Nick \& Thacker, James W. (2013). Effective Training. System, Strategies and Practices. 5th edition. New Jersey, Upper Saddle River: Pearson Education. Inc.

H. Frazis and M. A. Loewenstein. (2006). On The Job Training, Volume 2 Issue 5.Outside North America: now Publishers Inc.

Marihot, Manullang. (2001). Manajemen Sumber Daya Manusia. Yogyakarta:BPFE.

Rivai, Veithzal, (2006). Manajemen Sumber Daya Manusia untuk Perusahaan : dari Teori Ke Praktik, Edisi Pertama, Penerbit PT. Raja Grafindo Persada, Jakarta

Sutoto, D. (2004). Dimensi Tingkat Kompetensi. Artikel. Http://Www.Petra.Ac.Id/Pulsit/Journals/Dir.Php). 